ISA

Arboriculture \& Urban Forestry 2016. 42(3): 133-145

\title{
Testing a New Approach to Quantify Growth Responses to Pruning Among Three Temperate Tree Species
}

\author{
Matt Follett, Charles A. Nock, Christian Buteau, and Christian Messier
}

\begin{abstract}
In settled areas, electrical line safety is maintained by pruning encroaching trees. Identifying key predictors of branch elongation growth rate following pruning would assist in developing predictive models and optimizing pruning cycles. However, measuring branches in trees near electrical lines is complex and challenging. This paper describes an innovative approach using a handheld laser rangefinder to safely and accurately estimate growth from the ground. In-tree and ground-based laser measurements were highly correlated. This was followed by testing for correlations between branch growth response over a number of years after pruning and many biotic and abiotic factors for Fraxinus pennsylvanica, Acer platanoides, and Acer saccharinum, in the city of Montréal, Canada. In a sample of 59 trees, A. saccharinum had the greatest branch growth, followed by F. pennsylvanica, and finally A. platanoides. Branch growth increased following pruning and subsequently strongly declined, with A. platanoides declining the fastest. Branch inclination angle was positively correlated with growth rate for two species, but not for A. saccharinum. Among the types of pruning used, directional pruning techniques resulted in the least branch regrowth rate. Tree diameter was weakly related to branch growth rates. These results suggest that while growth conditions for street trees may be perceived as homogenous, there is substantial variation in branch growth response. This variation may be related to pruning history, or unmeasured abiotic or biotic variables. Estimating pruning cycle duration is a complex task and further work is needed to develop a predictive model for more accurate estimation of return times.

Key Words. Acer platanoides; Acer saccharinum; Branch Growth; Canada; Fraxinus pennsylvanica; Growth Modeling; Laser Rangefinder; Pruning; Québec; Urban Forestry; Utility Pruning; Vegetation Management.
\end{abstract}

Urban trees play an important role in the infrastructure of cities by providing numerous ecosystem services (Dwyer et al. 1992; Bolund and Hunhammar 1999; Kuo and Sullivan 2001; Nowak et al. 2008). However, trees must also coexist with other elements of city infrastructure due to the compact nature of urban development. Where electrical utility line vegetation clearance is maintained by pruning encroaching trees, periodic returns are required to maintain adequate clearance from electrical conductors. Estimating return time for vegetation management is an overarching concern for managers (Rees et al. 1994; Christian Buteau, pers. comm. 2012). Return time for vegetation management could be optimally planned using the clearance distance at the last pruning cycle and rates of regrowth of shoots that will likely be the first to intercept electrical lines.

A number of factors will likely influence this rate of regrowth, including climate, species, site factors, and genetic and phenotypic variation. However, there is little published information on specific branch regrowth rates following pruning. While rates of gap closure as a result of lateral branch extension has been studied in managed forests (Heichel and Turner 1984; Runkle and Yetter 1987), such studies are difficult to extrapolate to urban tree branch regrowth in response to pruning for a number of reasons. First, urban tree species composition is often dissimilar to managed forests. Second, research on tree canopy growth response to gap creation, documenting branch elongation to altered environmental conditions in and near the crown (Canham 1988; Springmann et al. 2011), is difficult to extrapolate to urban tree responses to pruning. Finally, urban tree growth rates often differ from neighboring forests due to differences in environmental conditions (Close et al. 1996; Gregg et al. 2003; Searle et al. 2012). 
Branch growth is directly related to light interception during the growing season (Ramos and Grace 1990; Saxe et al. 1998; Stoll and Schmid 1998; Krueger et al. 2009). Ramos and Grace (1990) found higher maximal rates of photosynthesis in high light versus low light conditions, while Stoll and Schmid (1998) showed an increase in overall length of growth in higher light conditions compared to shaded conditions after a disturbance in light availability. Overall growth rates are generally correlated with species shade tolerance, and under similar growing conditions, shade-intolerant species typically show faster rates of growth in all but the lowest light conditions (McClendon and McMillen 1982; Kitajima 1994; Walters and Reich 1996; Krueger et al. 2009). Available soil volume or compaction levels-and subsequent water and nutrient availability-have also been linked to urban tree growth and health (Heilman 1981; Krizek and Dubik 1987; Grabosky and Bassuk 1995; Grabosky and Gilman 2002; Sala and Hoch 2009). Available carbohydrate content within stems and branches has been linked to growth and vitality (Chapin et al. 1990; Magel et al. 2000; Kosola et al. 2001).

Despite this solid foundation of research on plant growth, there is little specific information on branch growth rates of different tree species within urban areas. Anecdotally, the industry recognizes that pruning can elicit a strong branch elongation response in the years following, and a few studies have reported on the trend. For example, Rom and Ferree (1985) reported an increase in growth rates in the year following pruning, as pruning severity increased. In addition, Goodfellow et al. (1987) noted that "round-over pruning" (assumed to mean internodal heading cuts) resulted in higher branch growth rates than "natural pruning" (assumed to mean reduction to a lateral branch) following routine utility line clearance.

One likely reason for the lack of research on pruning and its effect on branch growth rates in urban areas and around electrical conductors is the difficulty in safely taking measurements given the risk of personal injury of working within the proximity of energized conductors. Safe approach distances to exposed electrical conductors is regulated by worker safety laws, requiring certified workers to approach within three meters of exposed energized conductors over
750V (Ontario Occupational Health and Safety Act 2012). This poses a challenge for data acquisition, as the equipment and personnel required to quickly access a large sample becomes difficult to procure or is prohibitively expensive.

This study sought to: 1) develop a safe and efficient method of quantifying annual branch elongation in tall trees within proximity to electrical wires, 2) document rates of re-growth following pruning for a number of dominant urban tree species to help optimize pruning cycles, and 3) evaluate how different biotic and abiotic variables influence the rates of branch re-growth among the three tree species.

\section{METHODS}

\section{Site}

All trees in this study were located within the confines of the City of Montréal, Québec, Canada $\left(45^{\circ} 30^{\prime} \mathrm{N}, 73^{\circ} 34^{\prime} \mathrm{W}\right)$. Summers are typically humid with a daily average of $21^{\circ} \mathrm{C}$ to $22^{\circ} \mathrm{C}$ in July, while winters are cold with an average daily temperature of $-10^{\circ} \mathrm{C}$ in January. Average annual precipitation is approximately $980 \mathrm{~mm}$.

\section{Tree Selection}

Based on their abundance and importance to local electric line-clearance programs, three tree species were selected for study: Fraxinus pennsylvanica Marsh., Acer platanoides L., and Acer saccharinum L. The study sampled trees previously pruned as part of routine electrical conductor clearance work. To limit variance of pruning distance from the conductors due to voltage level or construction type, only single phase-to-ground type electrical construction was considered. In Montréal, this network is largely adjacent to streets on municipal property, thus all the trees in the study were owned by the City of Montréal. This further reduced variation as the trees were pruned for street and sidewalk clearance to similar specifications. The selected street blocks are primarily urban to suburban and within $6 \mathrm{~km}$ of the downtown area. A total of 59 trees were sampled in six different boroughs. Trunk diameter ranged from $28 \mathrm{~cm}$ to $112 \mathrm{~cm}$, tree height ranged from $7.6 \mathrm{~m}$ to $22 \mathrm{~m}$, and crown size ranged from $127 \mathrm{~m}^{3}$ to $4,642 \mathrm{~m}^{3}$. Data were collected from August 2011 through to February 2012. 
Electrical line-clearance pruning in Montréal typically involves pruning entire street blocks during a pruning cycle; as such, all the trees in a plot would have been pruned at the same time. For the streets sampled in this study, this ranged from three to five years prior to the sample date. To estimate the pruning date, epicormic growth from heading cuts was used to back-date the cut. This assumed that the growth sampled occurred the year of pruning; however, late summer or autumn pruning may not have induced growth during that year; as such, the pruning date recorded would have been the following year.

\section{Measuring Annual Branch Extension with a Laser Rangefinder}

To measure branch extension without climbing near the electrical corridor, a ground-based measurement system was developed and tested using a handheld laser rangefinder/clinometer (TruPulse ${ }^{\varpi}$ 360, Laser Technology Inc., Centennial, Colorado, U.S.). This allowed for rapid, relatively inexpensive data acquisition, while eliminating the need for aerial lift access or climbers certified to work in proximity to the electrical conductors. All linear measurements were taken from the ground using the laser rangefinder. The device measures distance to target, as well as inclination angle and azimuth of the device. It can then calculate the distance between any two reflective points (Figure 1). The device was used for all in-crown measurements, as well as distance to the nearest building and building height. The device resolution is $10 \mathrm{~cm}$ for linear lengths (rounding to nearest tenth) and is specified as accurate to \pm 0.25 degrees for inclination, \pm 1 degree for azimuth. The viewfinder/scope includes $7 \times$ magnification to allow for improved sighting accuracy. To assess the device's realized accuracy for total branch length and internodal growth, researchers conducted field tests and verified laser measurements with in-tree linear measurements of 19 branch samples of F. pennsylvanica (Figure 2).

For each tree included in the study, measurements of annual branch extension growth were collected for: a) branches that had regrown into the utility corridor following pruning in 2008 2010 (response growth), and b) control growth of unpruned branches growing on the periphery of the crown. For control growth, exterior branches that were distant to the pruning site and visually assessed to be indicative of the average growth rate for the tree were selected. For response growth, the longest branches from each of the selected pruning response types that had regrown into the utility corridor were selected. This was based on a visual assessment during initial inspection of each tree, and followed up by routine measurement of the largest branches to select appropriate growth. Annual growth increments were measured as the distance between successive bud scars, or architectural markers. In temperate areas, trees exhibit yearly rhythmic growth. When the bud scales that protect the terminal bud during overwintering are shed, they leave behind a prominent marking on the stem referred to as bud scars. As a new set of bud scales is developed for each overwintering bud, each year of growth is marked by the bud scar. Therefore, the bud scars allow for precise delineation of the length added each year, and for many species can be used to measure past growth for several years before present depending on species characteristics (Canham 1988; Runkle 1992; King 2003). When the twig eventually outgrows the bud scars, branch architecture can be used to delineate yearly growth for several more years (Millet et al. 1999); thus, it is possible to determine five to six years of yearly growth through visual analysis of branch features.

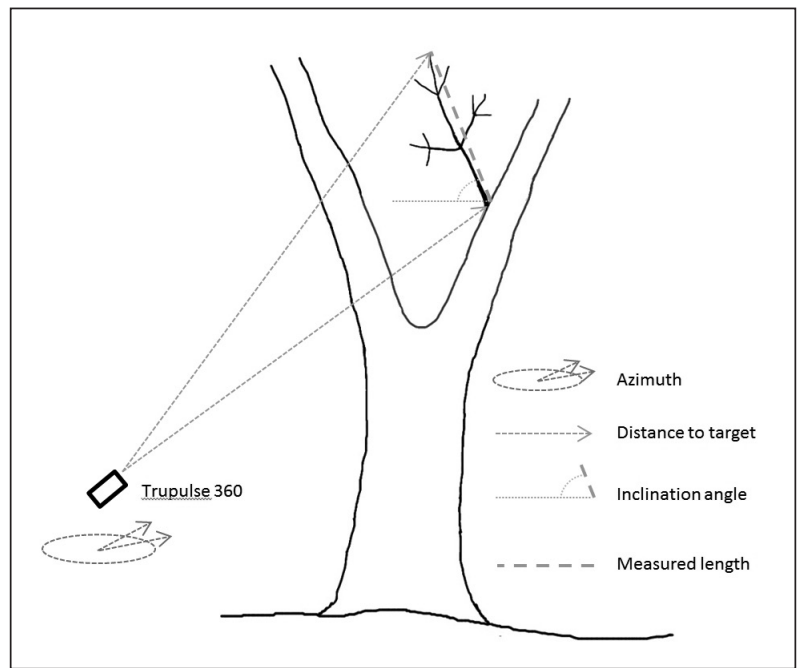

Figure 1. Method for measuring branch length. The TruPulse 360 measures distance to target, inclination, and azimuth. It can then calculate the straight line distance between two targets. 


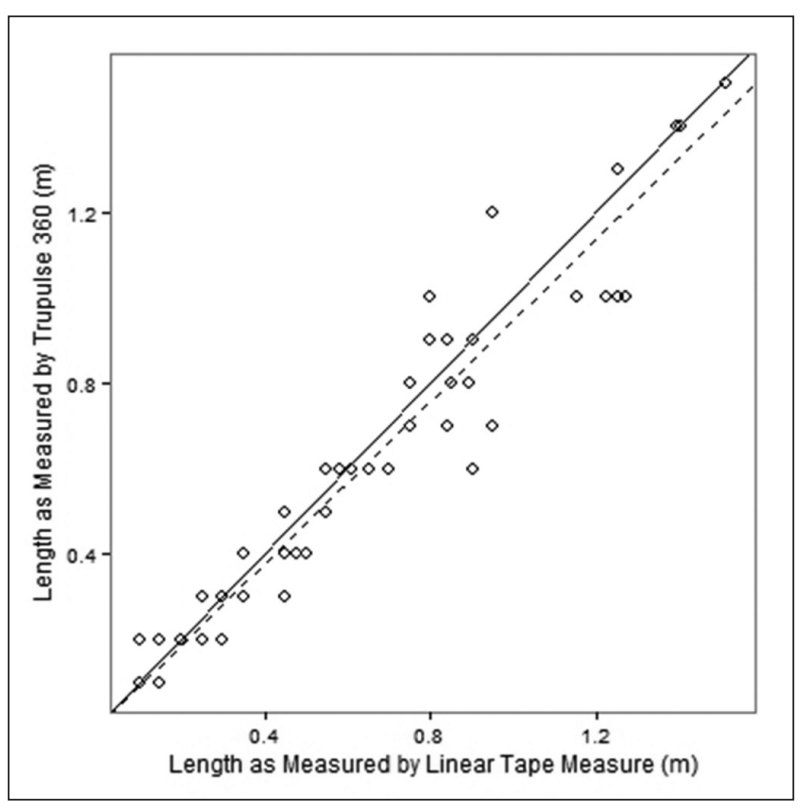

Figure 2. Correlation of laser (TruPulse 360) and in-tree linear tape measurements of annual pruning response growth in $F$. pennsylvanica. Mean length $=0.52 \mathrm{~m}, \mathrm{SD}=0.354, \mathrm{R}^{2}=$ $0.98, F(1,92)=4844, P<0.001$, slope $=0.948, \mathrm{~N}=93$.

\section{Pruning Response Growth Classification}

Response growth was classified into one of the three following categories: 1) epicormic growth, 2) growth from directional pruning, and 3) growth from heading cuts (Figure 3). Epicormic growth was considered any branch occurring from epicormic or latent buds on a parent stem (Shigo 1991). This included growth from past epicormic sprouting sites that had been cut back to the parent stem during the previous pruning cycle. Directional pruning was defined as any pruning back to a lateral limb approximately one-third the diameter of the parent stem; in this case, the response growth measured was growth occurring on the remaining lateral limb (Figure 3b). In initial pilot work, researchers observed that response growth (on the study species) following directional pruning was mainly from the terminal bud of the uncut lateral branch, and not from epicormics originating at the pruning cut. A heading cut was any internodal cut where the closest remaining lateral was less than one-third the diameter of the parent stem; the resulting epicormic growth was then measured (Figure 3c). The defining difference between the "epicormic growth" classification and the "heading cut" was the cut to the parent stem; in the case of the heading

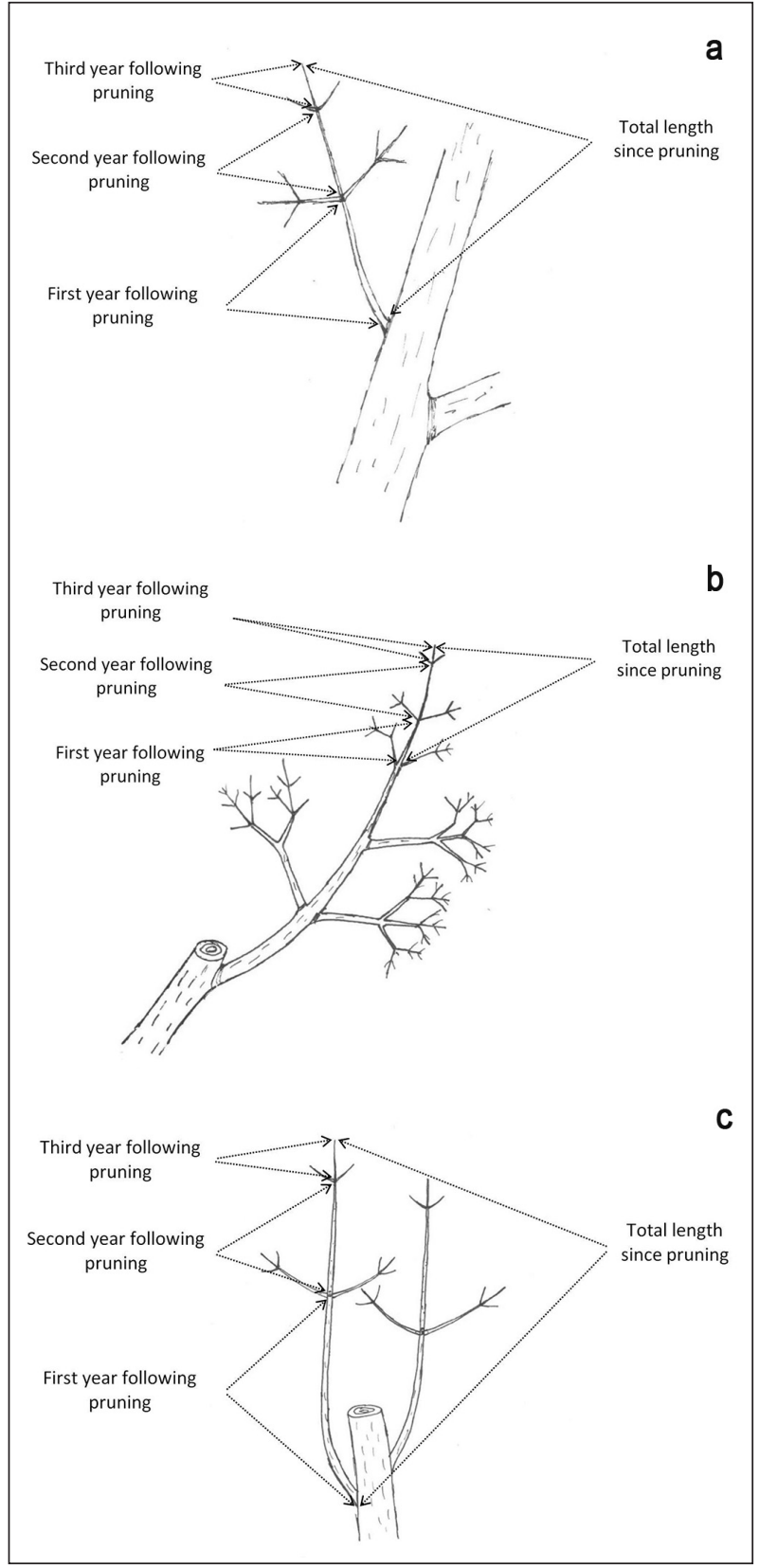

Figure 3. Response growth classification and measurement: a) epicormic growth, b) directional cut and typical measurement, c) heading cut and typical regrowth.

cut, the parent stem was cut internodally versus the epicormic growth, which could originate anywhere in the tree, typically on larger scaffold limbs, without a localized cut to the parent stem. The diameter of the parent stem was also categorized; for epicormic growth, this was at the growth site, whereas for directional and heading cuts, this was at the pruning cut. When this was less than $20 \mathrm{~cm}$, or less than the resolution of the TruPulse 360 (typical for head- 
ing and directional cuts), the diameter was estimated (e.g., $5 \mathrm{~cm}, 10 \mathrm{~cm}, 15 \mathrm{~cm}$ increment categories).

Unpruned portions of each crown were measured to gain a baseline for individual tree branch growth. Control length in many cases was less than $10 \mathrm{~cm}$ per annum. In this case, the length was visually estimated and then categorized by measuring a total length portion (i.e., five years growth $=40 \mathrm{~cm}$ ) of the branch with the TruPulse 360 . Then dividing up the total length and estimating the individual yearly segment lengths, and assigning a category $(5 \mathrm{~cm}, 10 \mathrm{~cm}, 15 \mathrm{~cm})$. In some cases, this required the use of standard $10 \times$ binoculars to more accurately estimate the individual segment lengths.

\section{Variables Influencing Rates of Branch Regrowth}

A suite of variables was measured that could influence the rates of regrowth into the utility corridor. A complete list is shown in Table 1 and grouped by categories: a) environment, b) whole tree, and c) within-crown variables. In some cases, these variables can be considered proxies for other variables that would be hard to measure in the study design. For example, the distance between stems on V-trim trees could be considered a proxy for light availability, and parent stem diameter could be a proxy for available stored reserves, such as carbohydrates. It was assumed that soil and moisture resources are likely to be correlated with the percentage of soil under the crown not covered with hardscaping (generally asphalt, concrete for sidewalks, and walkways on private property), and this measure has been used in previous work (USDA 2003; Nowak et al. 2008). Trim type was classified into two categories: V-trims and side trims (Dahle and Holt 2006). $\mathrm{V}$-trims were any tree where the utility corridor passed through the crown, while side trims were exclusively those that did not have crown separated by the utility corridor. Crown size was calculated by measuring the crown width in the two cardinal directions, as well as the total tree height, and the base of the "green" crown. The following formula:

[1] Crown Size $=\pi \bullet($ Height - Base Height $) \bullet$ $(0.5 \bullet$ width east/west $) \bullet(0.5 \bullet$ width north/south $)$

was then used to give an estimate of the crown volume. Branch height was the measured distance from the ground to the base of sampled growth. The azimuth and inclination of the regrowth was also recorded.

In total, 59 trees were sampled, the number of each tree type and number of individual limbs sampled are summarized in Table 2. To account for variance in the number of years since the last pruning episode across the data set, all results in this study utilize four years of growth, starting from the year of pruning. This study primarily examines and reports on the annual growth segments (distance between annual nodes) as a response, rather than the total length of extension since the most recent pruning episode, thereby eliminating a conflict of some samples having five or six years of growth since the last pruning.

Table 1. Summary of explanatory variables measured.

\begin{tabular}{lll}
\hline Environment & Whole tree & Within crown \\
\hline Distance to adjacent buildings & Species identity & Regrowth type \\
Adjacent building height & Crown width (two dimensions) & Branch origin height \\
\% exposed soil under crown & Crown height & Parent stem diameter \\
Trim type, V or side (light exposure) & Crown base height & Regrowth inclination \\
Azimuth of V-trim (light exposure) & DBH & Regrowth azimuth \\
$\begin{array}{l}\text { Stem distance (between V-trim main } \\
\text { stems - light exposure) }\end{array}$ & & Regrowth length (annual and total length) \\
\hline
\end{tabular}

Table 2. Sample sizes for tree species and specific growth types.

\begin{tabular}{|c|c|c|c|c|c|c|}
\hline & Trees & $\begin{array}{l}\text { Response } \\
\text { growth }\end{array}$ & $\begin{array}{l}\text { Heading } \\
\text { growth }\end{array}$ & $\begin{array}{l}\text { Epicormic } \\
\text { growth }\end{array}$ & $\begin{array}{l}\text { Directional } \\
\text { growth }\end{array}$ & $\begin{array}{l}\text { Control } \\
\text { growth }\end{array}$ \\
\hline Fraxinus pennsylvanica & 28 & 111 & 20 & 82 & 9 & 66 \\
\hline Acer platanoides & 15 & 58 & 18 & 30 & 10 & 30 \\
\hline Acer saccharinum & 16 & 62 & 6 & 47 & 9 & 28 \\
\hline
\end{tabular}




\section{Statistical Analysis}

All statistical analysis was completed using R: A Language and Environment for Statistical Computing. Linear modeling was completed using the "Im" function in $\mathrm{R}$, while ANOVA's utilized the "aov" function, and Tukey's tests were conducted with the "Tukey HSD" function. In the case of reporting $\mathrm{R}^{2}$ values, the adjusted $\mathrm{R}^{2}$ values are reported whenever multiple variables are included in the linear regression analysis. Unless otherwise stated in the results, tests were initially done with the species pooled, then the model was fit to each species individually. In some cases, there was testing to investigate the differences between species, and this is specified in the results or figures. One-way ANOVA testing was used to test differences in means for all group tests, such as species, regrowth type, or trim type, whereas linear models were fit to all scalar variables.

\section{RESULTS}

\section{Accuracy of TruPulse 360 for Branch Segment Length Measurements}

To assess how well the laser method captured branch growth, in-tree measurements made with a tape measure were compared to the laser derived measurements made from the ground; using linear regression and examining how close the slope was to unity, as well as the $\mathrm{R}^{2}$ of the relationship. For the 19 branch samples of F. pennsylvanica, the laser derived measurements for annual pruning response growth were in close agreement with in-tree measurements [mean length $=0.52 \mathrm{~m}, \mathrm{SD}=0.354 \mathrm{~m}, \mathrm{R}^{2}=0.98, \mathrm{~F}$ $(1,92)=4844, P<0.001$, slope $=0.948]$ (Figure $2)$. Results for the total branch length since the last pruning [mean length $=2.52 \mathrm{~m}, \mathrm{SD}=0.77$ $\mathrm{m}, \mathrm{R}^{2}=0.98, \mathrm{~F}(1,18)=1223, P<0.001$, slope $=0.998]$ were similar to those for annual branch growth (total length data not shown in Figure 2).

\section{Branch Growth in Response to Pruning} Using ANOVA testing (one-way), for all measured years in this study, the documented mean annual branch response growth following pruning was highest in A. saccharinum, followed by $F$. pennsylvanica, while A. platanoides was the lowest (Figure 4). Acer platanoides was significantly dif- ferent from $A$. saccharinum, and $F$. pennsylvanica $(P<0.001)$, however there was no significant difference between A. saccharinum and F. pennsylvanica (Figure $4, P<0.001$, Tukey's HSD test).

Linear regression analysis of the length of annual branch response growth showed a strong decline over time in A. platanoides and F. pennsylvanica, but only moderately in $A$. saccharinum (Figure 5). While the results were significant, there was a lot of variation, as can be seen by the relatively low $\mathrm{R}^{2}$ values, particularly for $A$. saccharinum. Results are as follows; all species, $\mathrm{R}^{2}=0.169, P<0.001 \mathrm{~N}$ = 734; F. pennsylvanica, $\mathrm{R}^{2}=0.01, P<0.05, \mathrm{~N}=$ 369; A. platanoides, $\mathrm{R}^{2}=0.05, P<0.005, \mathrm{~N}=278$; A. saccharinum, $\mathrm{R}^{2}=0.005, P>0.05, \mathrm{~N}=252$. Comparing species, the rate of decline was greatest for $A$. platanoides (slope $=-0.07$ ), followed by $F$. pennsylvanica (slope $=-0.03$ ), and then $A$. saccharinum (slope $=-0.02$ ) (Figure 5). For all species, annual growth length of pruning response branches was much greater than unpruned (control) branch growth (two sample t-test, mean annual response growth length $=0.66 \mathrm{~m}$, mean control growth length $=0.15 \mathrm{~m}, P<0.001)$. Maxi-

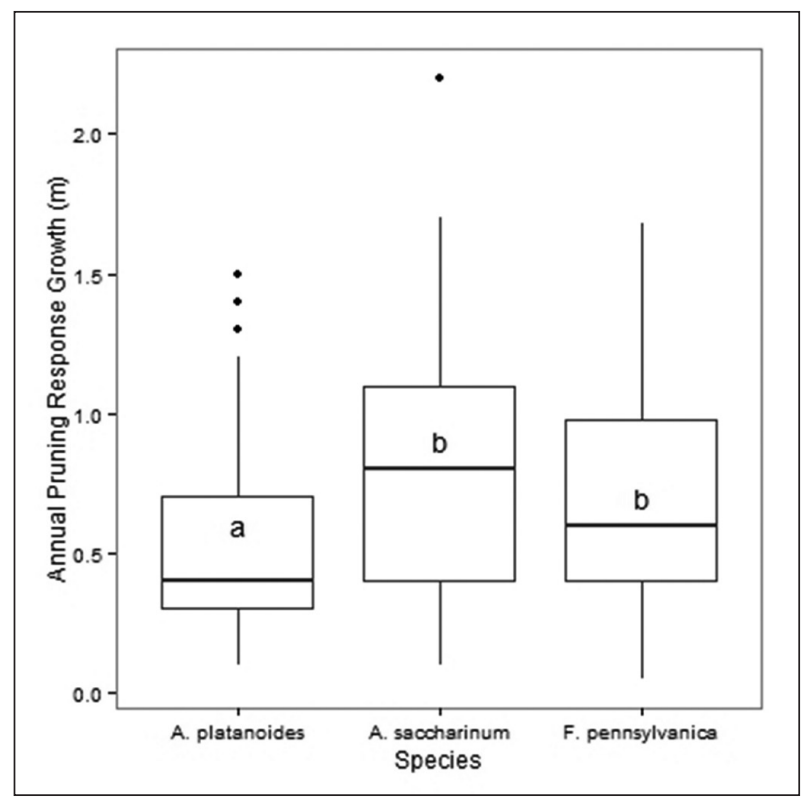

Figure 4. Comparison of annual pruning response growth for three urban tree species since the last pruning episode. The dark line of each boxplot represents the median, the upper and lower hinges are 75th and 25th percentiles, respectively, whiskers extend to highest and lowest values within the 1.5 inter-quartile range. Data points beyond the whiskers are outliers. Boxplots with same letters are not significantly different, Tukey's honestly significant difference HSD $P<0.001, \mathrm{~N}=734$. 


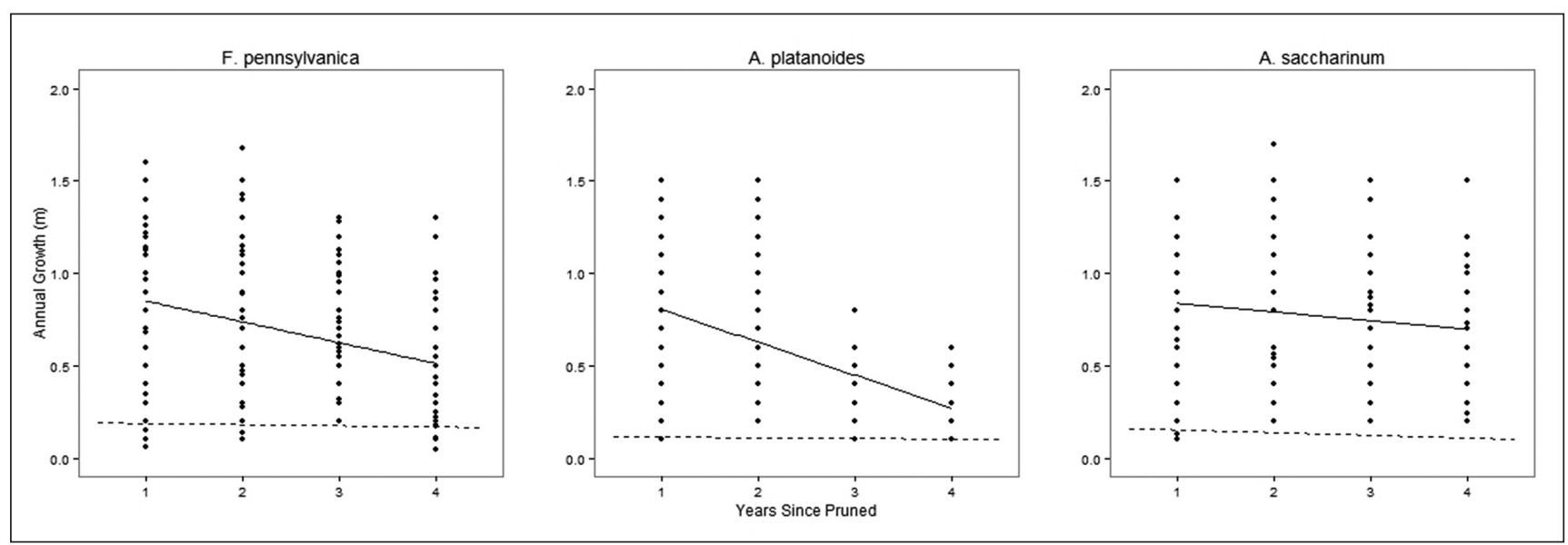

Figure 5. Relationship between length of annual growth and number of years elapsed since the last pruning episode. The solid line represents the regression line of the annual response growth, while the dotted line represents the regression line of the annual control growth. Linear regression of annual length on time with species interaction yielded; $R^{2}=0.169, P<0.001$, slope $=-0.18 \mathrm{~N}=$ 734. Fraxinus pennsylvanica, $\mathrm{R}^{2}=0.01, P<0.05$, slope $=-0.03, \mathrm{~N}=369 ; A$. platanoides, $\mathrm{R}^{2}=0.05, P<0.005, \mathrm{slope}=-0.07, \mathrm{~N}=278 ; A$. saccharinum, $\mathrm{R}^{2}=0.005, P>0.05$, slope $=-0.02, \mathrm{~N}=252$. Control growth statistics not reported.

mum length growth was generally found during the first year following pruning and reached approximately $1.5 \mathrm{~m}$ for all three species (Figure 5).

\section{Assessment of Branch Growth Predictors}

Of all the branch growth predictors tested, only a few showed significant relationships with regrowth rate. The correlation table (Table 3) lists respective variable relationship strength. In each case, the relationships with the species pooled were first tested (across all species data pooled together), and then separately within species.

Across all species pooled, directional pruning growth was significantly different from both epicormic growth and heading cut growth (Tukey's HSD test $P<0.001$ ) and resulted in the slowest branch growth following pruning, there was no significant difference between heading and epicormic growth. Within each species, results from the Tukey's test varied slightly (Figure 6), for A. platanoides directional pruning was significantly different $(P<$ 0.001 ) from both epicormic growth and heading cut growth, while epicormic growth and heading cut growth response was not significantly different. In the case of $A$. saccharinum, each type of response was significantly different $(P<0.05)$, while for $F$. pennsylvanica only heading growth was significantly different from the other two groups $(P<0.05)$.
The linear regression analysis of annual length on inclination while testing for species interaction yielded $\mathrm{R}^{2}=0.11 \mathrm{~F}(5,729)=18.8$, $P<0.001$, slope $=0.002, \mathrm{~N}=730$. Within each species the results are as follows; $F$. pennsylvanica, $\mathrm{R}^{2}=0.07, \mathrm{~F}(1,337)=27.44$, slope $=0.003$, $\mathrm{N}=338, P<0.001 ;$ A platanoides, $\mathrm{R}^{2}=0.14, \mathrm{~F}$ $(1,208)=35.54, P<0.001$, slope $=0.008, \mathrm{~N}=$ 209; A. saccharinum, $\mathrm{R}^{2}=0.007, \mathrm{~F}(1,188)=$ $1.46, P>0.05$, slope $=-0.002, \mathrm{~N}=189$ (Figure 7).

Height of the origin of regrowth had a weak negative correlation with regrowth rate in $A$. saccharinum $\left[\mathrm{R}^{2}=0.04\right.$, F $(1,188)=7.81, P<0.05$, slope $=$ $-0.05, \mathrm{~N}=189$ ], where growth originating higher on the tree was typically shorter than growth originating lower on the tree, but the relationship was not significant or very weak in the other species $[F$. pennsylvanica, $\mathrm{R}^{2}=0.0003, \mathrm{~F}(1,337)=0.11, P<1.0$, slope $=-0.004, \mathrm{~N}=338 ;$ A platanoides, $\mathrm{R}^{2}=0.02$, $\mathrm{F}(1,204)=3.99, P<0.05$, slope $=-0.06, \mathrm{~N}=205]$.

Of the tree size variables investigated, only parent stem diameter (the size of the limb the regrowth originated from) showed significant results $(P<0.001)$, pooled species $\mathrm{R}^{2}=0.02$, $\mathrm{F}(1,733)=20.56, P<0.001$, slope $=0.005, \mathrm{~N}=$ 734 ), and only $A$. saccharinum showed a significant relationship between stem diameter and regrowth $\left(\mathrm{R}^{2}=0.06, \mathrm{~F}(1,188)=13.28, P<\right.$ 0.001 , slope $=0.007, \mathrm{~N}=189)$. The other species showed no significant relationship between stem or tree size and response growth rate (Table 3). 
Table 3. Relationships between individual factors measured and branch regrowth for all species and individual species.

\begin{tabular}{|c|c|c|c|c|c|c|c|c|c|}
\hline \multirow[t]{2}{*}{ Variable } & \multirow[t]{2}{*}{ Effect on } & \multicolumn{2}{|c|}{ All species } & \multicolumn{2}{|c|}{ F. pennsylvanica } & \multicolumn{2}{|c|}{ A. platanoides } & \multicolumn{2}{|c|}{ A. saccharinum } \\
\hline & & $P$ & $\mathrm{r}^{2}$ & $P$ & $r^{2}$ & $P$ & $\mathrm{r}^{2}$ & $P$ & $r^{2}$ \\
\hline Species & Annual length & $<0.001$ & & $\mathrm{Na}$ & & $\mathrm{Na}$ & & $\mathrm{Na}$ & \\
\hline Time & Annual length & $<0.001$ & 0.17 & $<00.05$ & 0.01 & $<0.001$ & 0.05 & NS & \\
\hline Regrowth type & Annual length & $<0.001$ & & $<.001$ & & $<0.001$ & & $<0.001$ & \\
\hline Inclination & Annual length & $<0.001$ & 0.02 & $<0.001$ & 0.07 & $<0.001$ & 0.14 & NS & \\
\hline Diameter PS & Annual length & $<0.001$ & 0.02 & NS & NS & NS & NS & $<0.001$ & 0.06 \\
\hline Branch height & Annual length & $<0.001$ & 0.02 & NS & NS & $<0.05$ & 0.02 & $<0.05$ & 0.04 \\
\hline $\mathrm{DBH}$ & Annual length & NS & & NS & & NS & & NS & \\
\hline Crown volume & Annual length & NS & & NS & & NS & & NS & \\
\hline Building height & Annual length & NS & & NS & & NS & & NS & \\
\hline Building distance & Annual length & NS & & NS & & NS & & NS & \\
\hline$\%$ soil exposure & Annual length & NS & & NS & & NS & & NS & \\
\hline Stem distance & Annual length & NS & & NS & & NS & & NS & \\
\hline Trim type & Annual length & NS & & NS & & NS & & NS & \\
\hline V-trim azimuth & Annual length & NS & & NS & & NS & & NS & \\
\hline Branch azimuth & Annual length & NS & & NS & & NS & & NS & \\
\hline
\end{tabular}

Note: Time $=$ number of years since last pruning episode; Stem distance $=$ the distance between the main stems in a V-trim type tree.

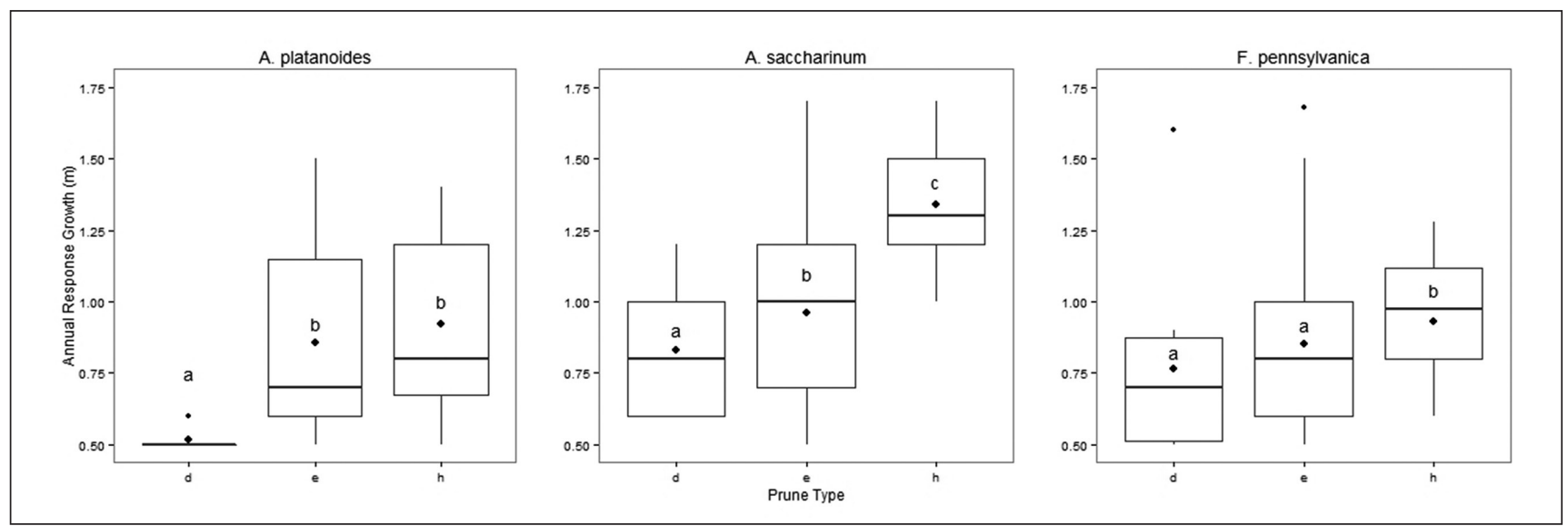

Figure 6. Comparison of annual response growth by response type for three species; directional pruning (d), epicormic growth (e), heading cut $(h)$. The dark line of each boxplot represents the median, the upper and lower hinges are 75th and 25th percentiles, respectively, whiskers extend to highest and lowest values within the 1.5 inter-quartile range. Data points beyond the whiskers are outliers, points inside the box are the mean. Boxplots with same letters (within species plots) are not significantly different at $P<0.05$ Tukey's honestly significant difference HSD.

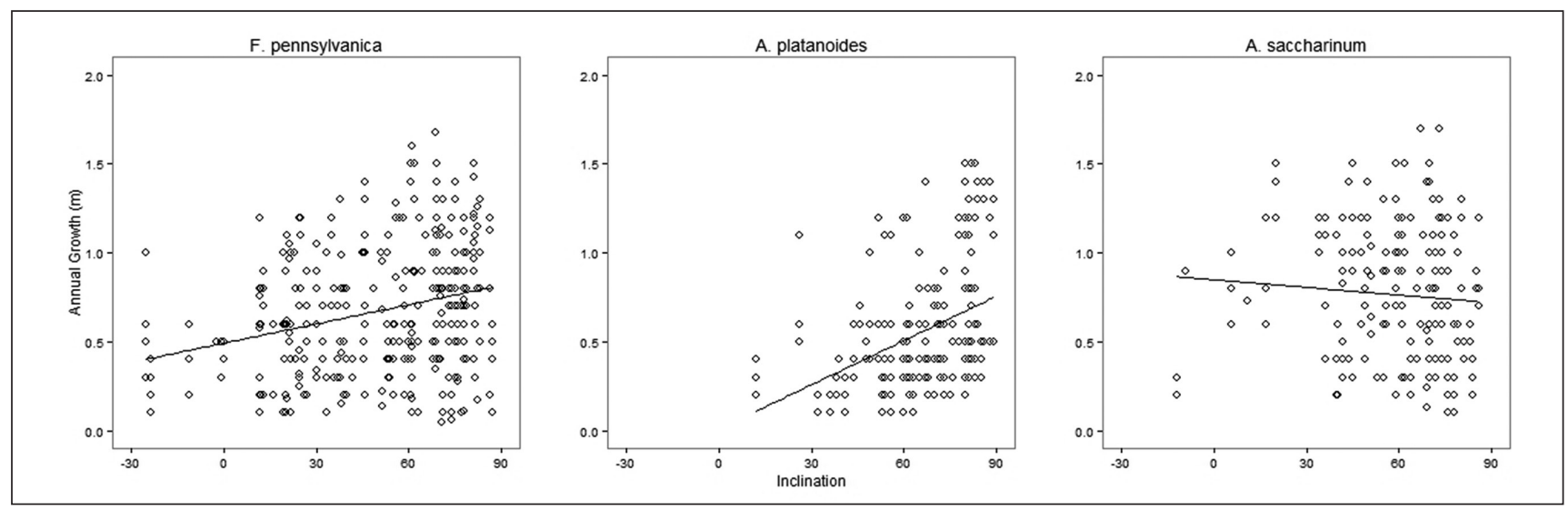

Figure 7. Annual growth of pruning response by branch inclination for three species. Zero degrees inclination corresponds with horizontal growth, and 90 degrees inclination corresponds with vertical, negative values are growth growing below horizontal (downwards). Linear regression of annual length on inclination with species interaction yielded: $R^{2}=0.11, P<0.001$, slope $=0.002$, $\mathrm{N}=730$; for $F$. pennsylvanica, $\mathrm{R}^{2}=0.04, P<0.001$, slope $=0.003, \mathrm{~N}=338$; $A$. platanoides, $\mathrm{R}^{2}=0.14, P<0.05$, slope $=0.008, \mathrm{~N}=205$; A. saccharinum, $\mathrm{R}^{2}=0.007, P>0.05$, slope $=-0.002, \mathrm{~N}=189$. 


\section{DISCUSSION}

For the species investigated in this study, researchers found that internode lengths of pruning response growth was generally longer than the $10 \mathrm{~cm}$ resolution limit of the TruPulse 360 . The laser measurement validation results show that within the bounds of this resolution, the TruPulse 360 can provide a safe, efficient, and effective way of measuring branch elongation growth in trees. This allowed the study authors to further develop the method and test for several abiotic and biotic factors affecting branch regrowth rates.

As others have previously shown (Rom and Ferree 1985; Goodfellow et al. 1987; Krueger et al. 2009), pruning or defoliation can elicit an increase in growth rate, specifically branch elongation. In this study, researchers also found that branch elongation into the recently pruned utility corridor area was shown to be much greater compared to unpruned portions of the crown. Growth was generally greatest in the first year following pruning and declined with time (Figure 5). One exception to this pattern was A. saccharinum. However, the method could not determine the specific timing of pruning within a growing season. Given the lower mean growth in the first year's growth for A. saccharinum compared to the other species, it is possible that several of the trees sampled were pruned late in the growing season, which resulted in a shorter period of time for branch regrowth. This illustrates one of the limitations of the study, as exact pruning dates are not known. Another limitation is possible variance in environmental factors and some tree size differences among tree species (see Appendix) that must be taken into consideration. Further sampling of a much larger data set could provide clearer answers now that the methods have been developed.

Few of the abiotic factors investigated for their influence on branch length growth showed a significant effect on regrowth rate (Table 3), while many of the biotic factors investigated were shown to affect regrowth rates: 1) species, 2) inclination angle of the growth response of branches (mainly positive), and 3) regrowth height (negative).

Inclination angle was expected to be correlated with growth length due to the relation to phototropism and geotropism (Chen et al. 1999; Sperry and Chaney 1999). The study found a slight posi- tive relationship with increasing inclination angle for A. platanoides and F. pennsylvanica but not for A. saccharinum. This last finding may hint at the ability to forage for available light. This result has direct implications for utility clearance; where A. saccharinum is concerned, greater horizontal distances from the utility (than typical) may be suggested to maintain clearance schedules.

Height of the origin of regrowth was negatively correlated with regrowth rate in A. saccharinum but not in A. platanoides or F. pennsylvanica. One possible explanation could implicate a decreased shading effect, where the lower scaffold limbs both distal to the trunk and below the pruning corridor were being pruned, as compared to more interior upper sections of the main stems potentially shaded by the upper crown. Another explanation could be greater hydraulic conductivity lower on the parent stem (Ryan and Yoder 1997; Becker et al. 2000; Ryan et al. 2006), but given the narrow range of heights measured in this study, further studies are warranted.

Tree size, including trunk diameter, crown volume, and parent stem diameter were considered possible predictors of growth, where stored reserves could be utilized in early growth before branch autonomy began (Chapin et al. 1990; Magel et al. 2000; Kosola et al. 2001; Mediene et al. 2002). Overall crown volume and trunk diameter showed no significant effect. Parent stem diameter for $A$. saccharinum showed significant results but with a very low $\mathrm{R}^{2}$.

The utility arboriculture industry has long been supportive of using pruning practices that minimize wounding and decrease return times by selecting pruning practices that reduce fast-growing epicormic growth, or suckering. This research shows that internodal heading cuts produced the longest regrowth, while directional pruning back to a lateral branch one-third of the parent stem diameter produced the shortest response growth (Figure 6). Furthermore, variance in the length of growth was lower for directional pruning response than epicormic growth or heading cuts. These results provide strong support to continuing promotion of directional pruning within the arboriculture industry and further studies to investigate the mechanisms involved in this lower response.

Available nutrient and moisture resources have been linked to tree growth rates (Krizek and Dubik 1987; Grabosky and Bassuk 1995; Grabosky and Gil- 
man 2002); however, the current study suggests that the response rate from pruning generally healthy trees may not be affected by the gradient of hardscape coverage in typical suburban environments where root exploration allows for access to root substrate over a much larger area then is exposed at the surface. Furthermore, the relatively broken hardsurface of the areas studied may allow for a high amount of moisture infiltration. This may not be the case in a newer setting where the hardscape is still relatively impervious, or in a more dense urban environment where tree pits are much more confined spaces.

The study collected data on three variables that could be correlated with available light levels at the pruning sites; trim type (V-trim vs side-trim), distance between V-trim main stems at phase height (giving an indication of the opening in the crown), and V-trim azimuth (light penetration through opening due to orientation). Of all these variables, none were significant across all species, or at a species level. Researchers presume that the relative high light environment, where overall most of the trees studied were in generally high light conditions, was cause for not picking up any signal.

\section{CONCLUSION}

The validity of using the TruPluse 360 as a device for measuring branch extension for regrowth following pruning has been proven. This method allows for the safe and efficient data collection at an effective rate. While there is great variation in branch growth following pruning, several key predictors have been identified. As predicted, species had an effect on growth rate, with $A$. saccharinum showing the highest rate of growth following pruning. Inclination angle of regrowth had a small positive effect on two of the species (F. pennsylvanica and A. platanoides), and little effect on A. saccharinum. This has implications for spatial planning around utility corridors where $A$. saccharinum exist, as more clearance may be required due to the propensity to develop strong horizontal growth. Pruning method had a strong effect on growth rate, and the data support industry initiatives to promote directional pruning in the utility corridor to reduce the rate of regrowth. While a few factors were identified as significantly affecting branch regrowth, the high proportion of re-growth not accounted for points for the need to investigate further other possible factors. Factors such as over- all tree vigor, carbohydrate storage, the timing of the pruning, and hydraulic position within the crown are possibly promising factors for future studies.

\section{LITERATURE CITED}

Becker, P., F. Meinzer, and S. Wullschleger. 2000. Hydraulic limitation of tree height: A critique. Functional Ecology 14:4-11.

Bolund, P., and S. Hunhammar. 1999. Ecosystem services in urban areas. Ecological Economics 29:293-301.

Canham, C.D. 1988. Growth and canopy architecture of shadetolerant trees: Response to canopy gaps. Ecology 69:786-795.

Chapin, F.S., E.D. Schulze, and H. A. Mooney. 1990. The ecology and economics of storage in plants. Annual Review of Ecology and Systematics 21:423-447.

Chen, R., E. Rosen, and P.H. Masson. 1999. Gravitropism in Higher Plants Plant Physiology 120:343-350.

Close, R.E., P.V Nguyen, and J. J. Kielbaso. 1996. Urban vs. natural sugar maple growth: I. Stress symptoms and phenology in relation to site characteristics. Journal of Arboriculture 22:144-150.

Dahle, G., and H. Holt. 2006. Branch strength loss implications for silver maple (Acer saccharinum) converted from round-over to V-trim. Arboriculture \& Urban Forestry 32:148-154.

Dwyer, J.F., E.G. Mcpherson, H.W. Schroeder, and R.A. Rowntree. 1992. Assesing the benefits and costs of the urban forest. Journal of Arboriculture 18:227-234.

Goodfellow, J.W., B. Blumreich, and G. Nowacki. 1987. Tree growth response to line-clearance pruning. Journal of Arboriculture 13:196-200.

Grabosky, J., and N. Bassuk. 1995. A new urban tree soil to safely increase rooting volumes under sidewalks. Journal of Arboriculture 4:187.

Grabosky, J., and E. Gilman. 2002. Measurement and prediction of tree growth reduction from tree planting space design in established parking lots. Journal of Arboriculture 30:154-164.

Gregg, J.W., C.G. Jones, and T.E. Dawson. 2003. Urbanization effects on tree growth in the vicinity of New York City. Nature 424:183-187.

Heichel, G.H., and N.C. Turner. 1984. Branch growth and leaf numbers of red maple (Acer rubrum L.) and red oak (Quercus rubra L.): Response to defoliation. Oecologia 62:1-6.

Heilman, P. 1981. Root Penetration of Douglas-fir Seedlings into Compacted Soil. Forest Science 27:660-666.

King, D.A. 2003. Allocation of above-ground growth is related to light in temperate deciduous saplings. Functional Ecology $17: 482-488$.

Kitajima, K. 1994. Relative importance of photosynthetic traits and allocation patterns as correlates of seedling shade tolerance of 13 tropical trees. Oecologia 98:419-429.

Kosola, K., D. Dickmann, E. Paul, and D. Parry. 2001. Repeated insect defoliation effects on growth, nitrogen acquisition, carbohydrates, and root demography of poplars. Oecologia 129:65-74.

Krizek, D.T., and S.P. Dubik. 1987. Influence of water stress and restricted root volume on growth and development of urban trees. Journal of Arboriculture 13:47-55.

Krueger, L.M., C.J. Peterson, A. Royo, and W.P. Carson. 2009. Evaluating relationships among tree growth rate, shade tolerance, and browse tolerance following disturbance in an eastern deciduous forest. Canadian Journal of Forest Research 39:2460-2469. 
Kuo, F.E., and W.C. Sullivan. 2001. Environment and crime in the inner city: Does vegetation reduce crime? Environment and Behavior 33:343-367.

Magel, E., W. Einig, and R. Hampp. 2000. Carbohydrates in trees. pp. 317-336. In: A. Grupta and N. Kaur (Eds.). Carbohydrate reserves in plants: Synthesis and regulation.

McClendon, J., and G. McMillen. 1982. The control of leaf morphology and the tolerance of shade by woody plants. Botanical Gazette 143:79-83.

Mediene, S., M.O. Jordan, L. Pagès, J. Lebot, and S. Adamowicz. 2002. The influence of severe shoot pruning on growth, carbon and nitrogen status in young peach trees (Prunus persica). Tree physiology 22:1289-96.

Millet, J., A. Bouchard, and C. Edelin. 1999. Relationship between architecture and successional status of trees in the temperate deciduous forest. Ecoscience 6:187-203.

Nowak, D.J., D.E. Crane, J.C. Stevens, R.E. Hoehn, J.T. Walton, and J. Bond. 2008. A ground-based method of assessing urban forest structure and ecosystem services. Arboriculture \& Urban Forestry 34:347-358.

Ontario Occupational Health and Safety Act. 2012. Ontario Occupational Health and Safety Act. Ontario Ministry of Labour.

Ramos, G., and J. Grace. 1990. The effects of shade on the gas exchange of seedlings of four tropical trees from Mexico. Functional Ecology 4:667-677.

Rees, W.T., T.C. Birx, D.L. Neal, C.J. Summerson, F.L. Tiburzi, and J.A. Thurber. 1994. Priority trimming to improve reliability. ISA Annual Conference. ISA, Halifax, Nova Scotia, Canada.

Rom, C.R., and D.C. Ferree. 1985. Time and severity of summer pruning influences on young peach tree net photosynthesis, transpiration and dry weight distribution. Journal of the American Society for Horticultural Science 110.

Runkle, J. 1992. Guidelines and sample protocol for sampling forest gaps. United States Department of Agriculture.

Runkle, J., and T. Yetter. 1987. Treefalls revisited: Gap dynamics in the southern Appalachians. Ecology 68:417-424.

Ryan, M.G., N. Phillips, and B.J. Bond. 2006. The hydraulic limitation hypothesis revisited. Plant, Cell, and Environment 29:367-381.

Ryan, M.G., and B.J. Yoder. 1997. Hydraulic limits to tree height, and tree growth: What keeps trees from growing beyond a certain height? 47:235-242.

Sala, A., and G. Hoch. 2009. Height-related growth declines in ponderosa pine are not due to carbon limitation. Plant, Cell, Environment 32:22-30.

Saxe, H., D. Ellsworth, and J. Heath. 1998. Tree and forest functioning in an enriched $\mathrm{CO}_{2}$ atmosphere. New Phytologist 139:395-436.

Searle, S.Y., M.H. Turnbull, N.T. Boelman, W.S.F. Schuster, D. Yakir, and K.L. Griffin. 2012. Urban environment of New York City promotes growth in northern red oak seedlings. Tree physiology 32:389-400.

Shigo, A.L. 1991. Modern Arboriculture: A Systems Approach to the Care of Trees and Their Associates. Shigo and Trees, Associates.

Sperry, C.E., and W.R. Chaney. 1999. Phototropism: Its implication for utility forestry. Journal of Arboriculture 25:43-47.

Springmann, S., R. Rogers, and H. Spiecker. 2011. Impact of artificial pruning on growth and secondary shoot development of wild cherry (Prunus avium L.). Forest Ecology and Management 261:764-769.
Stoll, P., and B. Schmid. 1998. Plant foraging and dynamic competition between branches of Pinus sylvestris in contrasting light environments. Journal of Ecology 86:934-945.

USDA. 2003. i-Tree eco user's manual. USDA.

Walters, M.B., and P.B. Reich. 1996. Are shade tolerance, survival, and growth linked? Low light and nitrogen effects on hardwood seedlings. Ecology 77:841-853.

Matt Follett (corresponding author)

Center for Forest Research

Département des Sciences Biologique

Université du Québec à Montréal

Montréal, Québec, Canada

Charles A. Nock

Center for Forest Research

Département des Sciences Biologique

Université du Québec à Montréal

Montréal, Québec, Canada

Faculty of Biology - Geobotany

University of Freiburg

Freiburg, Germany

Christian Buteau

Hydro-Québec

Montréal, Québec, Canada

Christian Messier

Center for Forest Research

Département des Sciences Biologique

Université du Québec à Montréal

Montréal, Québec, Canada

Institut des Sciences de la Forêt Tempérée

Département des Sciences Naturelles

Université du Québec en Outaouais

Ripon, Québec, Canada 


\section{APPENDIX \\ Tree Size and Soil Exposure ranges for all trees included in the study; $\mathbf{N}=$ number of samples, SD = standard deviation. SD, Min, Mean, and Max all rounded to nearest whole number.}

\begin{tabular}{|c|c|c|c|c|c|c|c|c|c|c|c|}
\hline \multirow[b]{2}{*}{$\mathrm{DBH}$} & \multicolumn{3}{|c|}{ All Species } & \multicolumn{3}{|c|}{ A. platanoides } & \multicolumn{3}{|c|}{ A. saccharinum } & \multicolumn{2}{|c|}{ F. pennsylvanica } \\
\hline & $\mathrm{N}: 59$ & SD: 16 & $\begin{array}{l}\text { Min: } 28 \\
\text { Mean: } 52 \\
\text { Max: } 112\end{array}$ & $\mathrm{~N}: 15$ & SD: 11 & $\begin{array}{l}\text { Min: } 32 \\
\text { Mean: } 54 \\
\text { Max: } 71\end{array}$ & $\mathrm{~N}: 16$ & SD: 18 & $\begin{array}{l}\text { Min: } 44 \\
\text { Mean: } 70 \\
\text { Max: } 112\end{array}$ & $\mathrm{~N}: 28 \quad$ SD: 7 & $\begin{array}{l}\text { Min: } 28 \\
\text { Mean: } 42 \\
\text { Max: } 72\end{array}$ \\
\hline $\begin{array}{l}\text { Parent stem } \\
\text { diameter }\end{array}$ & $\mathrm{N}: 231$ & SD: 11 & $\begin{array}{l}\text { Min: } 5 \\
\text { Mean: } 16 \\
\text { Max: } 90\end{array}$ & N: 58 & SD: 5 & $\begin{array}{l}\text { Min: } 5 \\
\text { Mean: } 8 \\
\text { Max: } 30\end{array}$ & $\mathrm{~N}: 62$ & SD: 14 & $\begin{array}{l}\text { Min: } 5 \\
\text { Mean: } 20 \\
\text { Max: } 90\end{array}$ & N: 111 SD: 10 & $\begin{array}{l}0 \text { Min: } 5 \\
\text { Mean: } 19 \\
\text { Max: } 40\end{array}$ \\
\hline $\begin{array}{l}\text { \% soil } \\
\text { exposure }\end{array}$ & N: 59 & SD: 27 & $\begin{array}{l}\text { Min: } 5 \\
\text { Mean: } 30 \\
\text { Max: } 95\end{array}$ & $\mathrm{~N}: 15$ & SD: 18 & $\begin{array}{l}\text { Min: } 10 \\
\text { Mean: } 50 \\
\text { Max: } 90\end{array}$ & $\mathrm{~N}: 16$ & SD: 32 & $\begin{array}{l}\text { Min: } 5 \\
\text { Mean: } 44 \\
\text { Max: } 95\end{array}$ & $\mathrm{~N}: 28 \quad$ SD: 7 & $\begin{array}{l}\text { Min: } 5 \\
\text { Mean: } 9 \\
\text { Max: } 30\end{array}$ \\
\hline
\end{tabular}


Résumé. Dans les régions habitées, la sécurité des réseaux aériens d'électricité est maintenue par l'élagage des arbres trop envahissants. Identifier les indicateurs clés du taux d'élongation des branches pourrait aider à développer des modèles prévisionnels et à optimiser les cycles d'élagage. Cependant, mesurer des branches d'arbres à proximité des lignes électriques est complexe et difficile. Cet article décrit une approche novatrice utilisant un télémètre laser de poche pour estimer en toute sécurité et avec précision, la croissance à partir du sol. Les mesures prises dans l'arbre et celles obtenues avec le télémètre laser étaient en étroite corrélation. Des tests furent par la suite effectués en vue d'établir des corrélations entre la croissance réactive des branches sur un certain nombre d'années après lélagage et plusieurs facteurs biotiques et abiotiques affectant des Fraxinus pennsylvanica, des Acer platanoides et des Acer saccharinum sur le territoire de la ville de Montréal, Canada. Parmi un échantillon de 59 arbres, l'A. saccharinum présentait la plus grande croissance réactive, suivi du $F$. pennsylvanica et enfin de l'A. platanoides. La croissance des branches s'est accentuée après lélagage pour ensuite ralentir fortement, l'A. platanoides était celui dont la croissance a déclinée le plus rapidement. L'angle d'inclinaison des branches était positivement lié à la rapidité de croissance de deux espèces, mais pas chez l'A. saccharinum. Parmi les types délagage utilisés, les techniques de coupe directionnelle ont entraîné le taux de repousse le moins élevé. Le diamètre des arbres n'avait que peu d'incidence sur le taux de croissance des branches. Ces résultats suggèrent que, bien que les conditions de croissance des arbres d'alignement puissent être perçues comme homogènes, il existe une variation considérable dans la croissance réactive des branches. Cette variation peut être liée à l'historique d'élagage ou à des variables abiotiques ou biotiques non mesurées. L'estimation du temps d'intervalle entre les cycles d'élagage est une tâche complexe et d'autres recherches sont nécessaires afin de développer un modèle prédictif pour une estimation plus précise du temps d'intervalle optimal.

Zusammenfassung. In besiedelten Gebieten wird die Sicherheit der Stromleitungen durch den Rückschnitt von aufkommenden Wuchs erhalten. Die Identifikation von Schlüsselmerkmalen zur Wachstumsrate von Ästen nach einem erfolgtem Rückschnitt würde dabei helfen, Vorhersagemodelle zu entwerfen und die Rückschnittintervalle zu optimieren. Dennoch ist die Messung von Ästen in Bäumen entlang der Stromleitungen komplex und herausfordernd. Dieses Papier beschreibt einen innovativen Ansatz zur Verwendung eines Handgerätes für die Lasermessung von Entfernungen, um sicher und akkurat das Wachstum vpm Boden zu messen. Die Lasermessungen im Baum und vom Boden aus waren hoch korreliert. Daraufhin folgte eine Abfrage, ob Korrelationen zwischen dem Nachwuchs der Äste im Laufe der Jahre nach dem Rückschnitt und vielen biotischen und abiotischen Faktoren bei Fraxinus pennsylvanica, Acer platanoides, und Acer saccharinum, in Montreal, Kanada, bestehen. In einer Auswahl von 59 Bäumen hatte Acer saccharinum den grössten Astzuwachs, gefolgt von Frax. penn. und schlussendlich Acer plat. Der Astzuwachs nahm nach dem Rückschnitt zu und verringerte sich nachfolgend stark, mit Acer plat. als schnellstem. Der Astausgangswinkel war bei zwei Arten, aber nicht Acer sacch. possitiv mit der Wachstumsrate korreliert. Unter den durchgeführten Rückschnittmethoden führte das Richtungseinkürzen zur geringsten Neuaustriebrate. Der Baumdurchmesser war nur schwach mit den Zuwachsraten der Äste korreliert. Diese Ergebnisse lassen darauf schliessen, dass, während die Wachstumsbedingungen für die Strassenbäume eher als homogen wahrgenommen werden, es doch eine grosse Variation beim Wachstum der Äste gibt. Diese Variation kann mit der Historie der Schnittmassnahmen in Verbindung stehen oder mit ungemessenen biotischen oder abiotischen Variablen. Es ist eine komplexe Aufga- be, die Dauer der Schnittzyklen zu schätzen und es ist weitere Arbeit erforderlich, um ein Vorhersagemodell für eine präzise Schätzung des Turnus zu entwickeln.

Resumen. En áreas pobladas, la seguridad de la líneas eléctricas se mantiene mediante la poda de los árboles que interfieren. La identificación de predictores clave de la tasa de elongación de la rama después de la poda ayudaría en el desarrollo de modelos de predicción y la optimización de los ciclos de poda. Sin embargo, la medición de las ramas de los árboles cerca de líneas eléctricas es compleja y desafiante. Este documento describe un enfoque innovador que utiliza un telémetro láser manual para estimar desde el suelo con seguridad y precisión el crecimiento de la rama. Las mediciones en el árbol y con láser desde tierra estuvieron altamente correlacionadas. Esto fue seguido por las pruebas de correlación entre la respuesta de crecimiento de la rama durante un número de años después de la poda y muchos factores bióticos y abióticos para Fraxinus pennsylvanica, Acer platanoides, y Acer saccharinum, en la ciudad de Montreal, Canadá. En una muestra de 59 árboles, A. saccharinum tuvo el mayor crecimiento de rama, seguido por F. pennsylvanica, y finalmente A. platanoides. El crecimiento de las ramas aumentó después de la poda y posteriormente disminuyó fuertemente, con $A$. Platanoides declinando más rápido. El ángulo de inclinación de la rama se correlacionó positivamente con la tasa de crecimiento de dos especies, pero no para A. saccharinum. Entre los tipos de poda utilizados, las técnicas de poda direccional resultaron en la menor tasa de rebrote. El diámetro del árbol estuvo débilmente relacionado con las tasas de crecimiento de la rama. Estos resultados sugieren que mientras las condiciones de crecimiento de árboles en las calles pueden ser percibidas como homogéneas, hay una variación sustancial en la respuesta de crecimiento de la rama. Esta variación puede estar relacionada con la historia de la poda, o variables abióticas o bióticas no medidas. La estimación de la duración del ciclo de poda es una tarea compleja y es necesario seguir trabajando para desarrollar un modelo predictivo para la estimación más precisa de los tiempos de retorno. 